\title{
Silva, Fernanda 0.; Sá, Jardélia R.; Gomes, Luciano da C.; Rosa, Marcus Vinícius de F.; Perussatto, Melina K.; Silva, Sarah C. A.; Santos, Sherol dos Pessoas comuns, histórias incríveis: a construção da liberdade na sociedade sul-rio-grandense
}

Hilton Costa ${ }^{\star}$

Porto Alegre: Ed. UFRGS; EST Edições, 2017. 112p.

O Brasil não sofre de falta de passado, talvez ele conviva com um excesso de passado. A questão que se coloca não é a ausência de uma noção do passado nacional, mas sim de qual passado se preserva. Essa ideia foi apresentada por Fernando Nicolazzi na conferência "História e Historiografia em tempos de transição”, oferecida no XVI Encontro Regional de História (Anpuh/Paraná, 2018). O passado que se cultiva no Brasil pode ser pensado nos termos propostos por Manoel Bomfim, ainda na primeira metade do século XX. Bomfim destacou em suas obras como o Brasil incorporava narrativas postas a deturpar sua trajetória histórica, bem como perpetuava um padrão de socialização calcado no parasitismo social (Bomfim, 2005; 2013). Esse passado que se cultiva é, em grande medida, aquele que perpetua as premissas estamentais da sociedade brasileira.

O ato de historiar é o de inquirir, de buscar evidências empíricas de realidades possíveis, envolvendo algum tipo de recriação e, concomitantemente, de criação de realidades, no sentido daquilo denominado por Pierre Bourdieu como efeito de teoria. No texto "A linguagem autorizada: as condições sociais da eficácia do discurso ritual”, publicado no Brasil no livro A economia das trocas linguísticas, o autor afirma que "a ciência social deve englobar na teoria

\footnotetext{
* Universidade Estadual de Maringá (UEM), Departamento de Ciências Sociais. Maringá, PR, Brasil. hcosta@uem.br <https://orcid.org/0000-0002-2140-7729>
} 
do mundo social uma teoria do efeito de teoria que, ao contribuir para impor uma maneira mais ou menos autorizada de ver o mundo social, contribui para fazer a realidade desse mundo..." (Bourdieu, 2008, p.82).

Seguindo tal sugestão, é possível pensar que a História do Brasil e de suas regiões é a criação mais ou menos intencional de determinadas realidades. A História do Rio Grande do Sul, sobretudo para as pessoas de fora desse estado, e talvez mesmo para quem é de lá, passa pela versão literária construída por Érico Veríssimo na saga O Tempo e o Vento (Veríssimo, 2004, 2004a, 2004b). A essa versão literária se combina outra que faz a História do Continente de São Pedro ser, em grande medida, a da imigração europeia (não portuguesa), fato disseminado para toda a região Sul do Brasil. Constitui-se, assim, um Brasil europeu (branco, diferente do restante da nação, marcado pela presença negra e indígena e pela miscigenação). Essas formas de pensar a História do Rio Grande do Sul, mais do que equivocadas, são maneiras de cultivar um determinado passado.

A obra Pessoas comuns, histórias incríveis: a construção da liberdade na sociedade sul-rio-grandense busca, em alguma medida, trazer outro passado à pauta, indicar outra realidade possível: "Por meio de uma narrativa produzida a várias mãos e com foco centrado nas experiências históricas da população negra do Rio Grande do Sul, nosso objetivo é contar a História Afro-Brasileira sob a ótica dos próprios protagonistas" (p.7). Autoras e autores visam propiciar "novas concepções a respeito da escravidão negra e do seu impacto na História do Brasil" e, evidentemente, do Rio Grande do Sul (p.7). Dessa forma, tem-se outra História do Rio Grande do Sul, outra realidade, apresentada em quatro capítulos.

“Através da história de personagens como a Preta Maria de Nação Benguela, Inácia, Preto Simão, Mantoca, Maria Cristalina...” (p.7), a obra desvela como se foram produzindo os lugares sociais da população negra brasileira e sul-rio-grandense. O livro faz uso de trajetórias de pessoas "comuns", fora do cânone mais usual de um determinado tipo de historiografia, para edificar outra História do Rio Grande do Sul e do Brasil.

O primeiro capítulo denota a presença negra na colonização do Continente de São Pedro, as "pessoas de cor" na condição de construtoras daquilo que viria a ser o Rio Grande do Sul. O foco recai também sobre as dimensões, nem sempre nítidas, da "fronteira" entre as pessoas livres, libertas e escravizadas, e sobre como a cor foi, desde muito cedo, no Brasil, um operador social fundamental; indicam-se, assim, os múltiplos significados da miscigenação. 
Ser uma pessoa de cor no Império do Brasil, tema central do segundo capítulo, guarda tantas ou mais contradições e impasses do que no período anterior; o liberalismo escravocrata do Império cuidou para a manutenção de tal contexto. Seguindo as trajetórias de pessoas como Inácia Garcia de Souza, Manoel Congo e outros, evidenciam-se os impactos das Leis de 1831, de 1850 e a do Ventre Livre, para além das discussões parlamentares e intelectuais. Tais legislações são trazidas para a vida cotidiana, indicando suas repercussões e contradições e mesmo a ineficiência prática do legislador perante o costume comum e a tradição.

A persistência da tradição, no sentido indicado por Arno J. Mayer (1987), fica ainda mais nítida nos capítulos 3 e 4 . As inseguranças e percalços da pós-abolição, do mundo das pessoas "livres", da igualdade republicana, são apresentados na perspectiva de pessoas que, pode-se dizer, viveram na prática a igualdade desigual da República dos Estados Unidos do Brasil. As dificuldades impostas à população negra e à sua organização, seja pela lei escrita, seja pelas não escritas, têm como um de seus efeitos a organização da comunidade afro-brasileira sul-rio-grandense, de modo a ser protagonista na organização do movimento operário no início do século XX - história essa pouco divulgada.

Uma das marcas mais interessantes de Pessoas comuns, histórias incríveis reside no trato das trajetórias femininas; as observações trazidas a lume sobre o protagonismo das mulheres negras na organização da comunidade afro-brasileira são riquíssimas, um tanto conhecidas na militância negra e no meio acadêmico, mas bastante obliteradas do passado do Brasil cultivado até o momento. Outro aspecto bastante bem trabalhado na obra é a construção do trabalho doméstico como o "lugar" da mulher negra. A construção social desse "lugar" se deu, sobretudo, a partir da desagregação da escravidão.

Esse livro, "trabalho coletivo idealizado e elaborado por professores, pesquisadores e militantes da causa negra, com visões plurais, num esforço conjunto de oferecer respostas à aplicabilidade das Leis 10.639/03 e 11.645/08..." (p.7), é, certamente, mais do que isso. A obra é um questionamento dos passados que se quer cultivar, um desafio em sentido bonfiniano, uma discussão da permanência das premissas escravocratas na sociedade brasileira, um debate historiográfico acerca da utilização das trajetórias de vida pela história, para além da compreensão de individualidades. Tudo escrito em linguagem acessível a diferentes públicos: discentes do ensino médio e superior e pesquisadores da temática (o expressivo levantamento bibliográfico presente ao final de cada capítulo é dos mais úteis). 


\section{REFERÊNCIAS}

BOMFIM, Manoel. A América Latina: males de origem. 2.ed. Rio de Janeiro: Topbooks, 2005.

. O Brasil na História: deturpação das tradições / degradação política. 2.ed. Rio de Janeiro: Topbooks; Belo Horizonte: PUC-Minas, 2013.

BOURDIEU, Pierre. A economia das trocas linguísticas: o que falar o que dizer. 2.ed. São Paulo: Edusp, 2008.

MAYER, Arno J. A força da tradição: a persistência do Antigo Regime - 1848-1914. São Paulo: Companhia das Letras, 1987.

VERÍSSIMO, Érico. O continente. São Paulo: Companhia das Letras, 2004. 2v. O retrato. São Paulo: Companhia das Letras, 2004a. 2v. . O arquipélago. v.1. São Paulo: Companhia das Letras, 2004b. 3v.

Resenha recebida em 15 de setembro de 2018.

Aprovada em 9 de outubro de 2018. 